\title{
EENE MILITAIRE BESCHOUWING OM'TREN'T DE KOLONIE SURINAME
}

DOOR

\section{J. W. VAN OORSCHOT,}

Het is ongeveer 250 jaar geleden, dat de Staten van Zeeland eene expeditie uitzonden naar de landstreek, gelegen aan de Noordkust van Zuid-Amerika, welke Guyana heet. De Republiek der Vereenigde Nederlanden voerde destijds den tweeden oorlog tegen Engeland en het doel van de expeditie was de stichting in Guyana van een Zeeuwsche kolonie in plaats van de daar aanwezige Engelsche. Dit doel werd bereikt. De Zeeuwsche vloot, die de Surinamerivier was opgezeild, zette haar landingsleger aan wal, het Nederlandsche gezag werd gevestigd in de aan die rivier gelegen plaats Paramaribo en bij den vrede van Breda (3I Juli I667) werd het met geweld van wapenen bezette gebied aan de Republiek der Vereenigde Nederlanden gelaten.

Sinds dien tijd is Suriname eene Nederlandsche kolonie gebleven, hoewel zij een paar malen door vijanden van ons vaderland werd aangevallen en gedurende den Napoleontischen tijd - van I804 tot I8I6 - zelfs onder Britsch bestuur is geweest.

De landbouwende kolonie kwam in de eerste eeuwen, nadat zij onder Nederlandsch bestuur was gekomen tot grooten bloei. Deze voorspoed stond in nauw verband met den slavenhandel, waardoor aan de plantages goede en goedkoope werkkrachten werden verschaft. De Afrikaansche negers, overzee naar Paramaribo gevoerd, werden op de markt aldaar verkocht, waar zij tusschen de 200 à 400 gulden per stuk opbrachten. De bestuurders van de plantages en vooral de over de slaven gestelde opzichters behandelden echter hunne gekochte werklieden in het algemeen zóó slecht dat dezen het leven dikwijls ondragelijk werd en zij poogden zich aan die onmenschelijke behandeling te onttrekken. Hierdoor ontstond het euvel der ,wegloopers”, dat het vreedzaam voortbestaan der kolonisten in gevaar bracht en zelfs 
enkele malen de geheele kolonie aan den rand van het verderf heeft gevoerd. De meest ondernemende en geestelijk en lichamelijk sterksten onder de slaven wierpen het juk der slavernij van zich af door de diep in het land liggende plantages te ontvluchten en zich in de daarachter gelegen oerbosschen te nestelen. Daar vereenigden zij zich tot troepen wegloopers, die later onder den naam van "marrons" bekend waren en de stamvaders werden van de thans nog in het binnenland van Suriname wonende boschnegers.

De marrons vergenoegden zich niet met het leiden van een vrij leven in de wildernis, maar hunne hand keerde zich tegen hunne vroegere meesters. Tendeele was dit het gevolg van de omstandigheid dat de bosschen den wegloopers niet voldoende voedsel opleverden en ten andere geschiedde het als wraakoefening. Op hunne strooptochten tegen de buitenplantages namen de marrons zooveel voorraden mede als zij konden bemachtigen en begingen zij uit wraak dikwijls de afschuwelijkste wreedheden.

Uit het vorenstaande blijkt, dat de kolonie Suriname zich in den loop der tijden had te verdedigen tegen buitenlandsche en binnenlandsche vijanden. Dit bracht mede de noodzakelijkheid om steeds eene krijgsmacht op de been te houden en de krijgsgeschiedenis van deze weermacht - die gedurende vele perioden een ware lijdenshistorie mag worden genoemd - vermeldt strijd zoowel tegen den buitenlandschen vijand (B. V.) als tegen den inlandschen vijand (I. V.).

De tijden zijn veranderd. De slavernij behoort over de geheele beschaafde wereld en ook in Suriname reeds tot het verleden. De nakomelingen der negerslaven gaan met opgeheven hoofd als vrije burgers in alle deelen van de kolonie rond en zijn nagenoeg niet meer tot arbeid op de plantages te bewegen. Van wegloopen is dus geen sprake meer en de voorheen zoo gevreesde marrons zijn thans de vreedzame boschnegers, die, evenals de Indianen, in kampen en dorpen ongehinderd en zonder zelf last te veroorzaken in de moeilijk te bereiken binnenlanden wonen.

Voor den geregelden strijd tegen den I. V. behoeft men dan ook thans in Suriname niet meer als voorheen, eene krachtige weermacht onder de wapenen te houden.

Door den B.V. is Suriname, nadat in I8I6 de Nederlandsche 
vlag weder in de kolonie werd geheschen, niet meer bedreigd. Gelukkig is ons vaderland in de achter ons liggende eeuw voor de rampen van een oorlog, waarin onze koloniën konden worden betrokken, gespaard gebleven en zelfs de groote wereldoorlog, die vlak over onze grenzen zoo hevig heeft gewoed, liet Nederland onaangetast.

Niemand is in staat, in de toekomst te zien en wat heden onmogelijk schijnt, kan morgen een feit zijn, doch, zooals de toestand in de wereld thans is, lijkt het niet aannemelijk dat Nederland in afzienbaren tijd gedwongen zal zijn de West-Indische koloniën tegen buitenlandsch wapengeweld te verdedigen. Hoewel men nog niet genaderd is tot den toestand van eeuwigen vrede en het egoïsme vermoedelijk ook in de toekomst een der hoofdfactoren in het verkeer tusschen de Staten zal blijven vormen, zoo mag toch worden gehoopt, dat voorgoed voorbij is de tijd, waarin men uit louter winstbejag elkaar de rijke koloniën ontroofde.

Suriname is een zeer rijk tropisch land, dat - al moge het zich op het oogenblik niet in een grooten bloei verheugen voor een ondernemenden bezitter, de gunstigste vooruitzichten opent en indien men nog in den ouden rooftijd leefde, zou het bezit van de kolonie zeker de moeiten en kosten van een gewapend optreden ruimschoots waard zijn. Daarom moet het ons tot dankbaarheid stemmen dat in het verkeer der volkeren, de brutale rooverij voorhands niet meer toelaatbaar is.

Maar er zijn voorbeelden in de geschiedenis - en die zijn niet van zoo ouden datum - dat op het bezit van eene kolonie of bezetting aanspraak werd gemaakt, onder het al- of niet gegrond motief, dat het belang van het begeerde gebied medebracht, dat het in andere handen overging - zoo niet goedschiks, dan kwaadschiks.

Zulke gedachten kunnen nog steeds op elk daarvoor gunstig oogenblik in het brein van een of ander staatshoofd opkomen of door eene daartoe aangezette pers of daarop gerichte politieke opinie in zulk een brein worden gegoten.

Indien Nederland - zooals het terecht schijnt te doen - er prijs op stelt, de West-Indische koloniën en zeer zeker Suriname met zijn vele en schoone mogelijkheden, te behouden dan is de ,Nederlandsche Regeering verplicht, met de hier bedoelde eventualiteit rekening te houden. 
In de eerste plaats moet daartoe dus zooveel mogelijk worden gezorgd, dat een voorwendsel, zooals zooeven bedoeld, niet kan worden gebruikt, om het naijverige buitenland de gelegenheid te verschaffen, tot het uitstrekken van de begeerige hand naar ons kostbaar erfdeel en men wake er zorgvuldig voor, dat ons het verwijt van wanbeheer zelfs niet met een ,schijn van recht” zou kunnen treffen.

Indien aan die voorwaarden is voldaan, kan de toekomst met vertrouwen worden tegemoet gezien en mocht dan nog niettemin de Kolonie met gevaar worden bedreigd, welaan dan blijft het laatste middel nog over, n.1. de verdediging van het ons eenmaal dooi de historie toevertrouwde gebied, met het volle recht aan de zijde van den verdediger.

Een B. V. (buitenlandsche vijand), die Suriname zou willen aanvallen, zou zich tegen de hoofdstad Paramaribo als object moeten richten, want Paramaribo is het hart van de uitgestrekte kolonie. Wie Paramaribo heeft, die bezit Suriname.

$\mathrm{Nu}$ is de hoofdstad steeds uit zee te bereiken en wel langs de breede, maar niet voor alle schepen bevaarbare Surinamerivier, die vooral aan en vóór hare monding in den Atlantischen Oceaan voor de scheepvaart niet gemakkelijk is, zoodat eene maritieme onderneming de Surinamerivier op, den aanvaller heel wat hoofdbrekens zou kosten vooral omdat de omstandigheden voor den verdediger zoo geschikt zijn, om den vijand tal van onaangename verrassingen te bereiden.

Zeer groote schepen met veel diepgang zijn niet bruikbaar en voor het gebruik van mijnen is de gelegenheid den verdediger hier bijzonder gunstig. Het ligt buiten het bestek van dit opstel, het technische gedeelte van dit onderwerp nauwkeurig te bezien, er moge worden volstaan met te constateeren, dat de geografische, politieke en strategische gesteldheid van de Kolonie zoodanig is, dat de quaestie van de verdediging van Suriname tegen een B. V. in hoofdzaak een maritiem vraagstuk is en derhalve nauw samenhangt met de vraag, of Nederland in de West-Indische wateren al dan niet eene vloot van eenige beteekenis zal moeten, wenschen en kunnen onderhouden.

Dat een geweldadig optreden van het buitenland tegen onze West-Indische koloniën, bij een behoorlijke politiek van Nederland, niet waarschijnlijk is, daarop werd reeds gewezen, maar 
nogmaals zij er met nadruk de aandacht op gevestigd, dat het onverantwoordelijk moet worden geacht, als men met de mogelijkheid geen rekening zou houden. Onze West-Indische koloniën, zoowel Suriname als de eilanden - en daarvan met name Curaçao - zijn juist in de tegenwoordige wereldconstellatie, een kostbaar pand, waarvan de waarde in de toekomst zeer waarschijnlijk aanmerkelijk zal toenemen. Daarom is het aanwezig zijn van eene Nederlandsche zeemacht van eenige beteekenis voor defensieve doeleinden in de West-Indische wateren een zaak van eminent belang.

Men behoeft gelukkig niet al te groote waarde te hechten aan de uitingen van sommigen die de Nederlandsche vloot zouden willen zien verdwijnen. Zulke stemmen komen waarschijnlijk slechts voort uit de gemoederen van hen, die onder den indruk der omstandigheden het brein niet koel kunnen houden en een volgend geslacht zal zich over eene dergelijke mentaliteit vroolijk maken.

Ook kan men zich niet van de zaak afmaken door te verklaren, dat Oost-Indië reeds zooveel van onze aandacht vergt en dat de belangen van het Oosten in de eerste plaats moeten worden behartigd. Niemand zal ontkennen, dat onze koloniën in Azië thans nog belangrijker zijn dan de West-Indische koloniën, maar waarom kan die ,groote knaap” dan niet wat meer voor zichzelf zorgen.

De landmacht is voor de verdediging van Suriname tegen den B. V. slechts van secundair belang.

Zonder hulp van de zeemacht is eene landmacht vrijwel waardeloos en indien de maritieme quaestie op bevredigende wijze is opgelost, dan is de aanwezigheid van een troepenmacht van beteekenis in Suriname voor de verdediging van de kolonie niet noodig. De tijd is voorbij, dat men met een paar voorlaadkanonnen op het fort Zeelandia aan de Surinamerivier bij Paramaribo gelegen, en met een paar kordate vendels Staatsche infanterie en ,,erentfeste”" schutterij in ijlings opgeworpen loopgraven aan den waterkant, kon trachten eene landing des vijands in de stad af te slaan.

Indien dan ook niet rekening moest worden gehouden met den I. V. (inlandschen vijand) dan zouden voor het onderhouden van een troepenmacht te land in Suriname niet voldoende motieven aanwezig zijn. 
Zooals reeds gezegd, wijst de krijgsgeschiedenis van Suriname op een voortdurend strijden tegen den I. V., die in de vroegste tijden van de nederzetting bestond uit de oorspronkelijke bewoners - de Indianen - en later werd gevormd door de weggeloopen slaven, de z.g. „marrons”. Noch de thans aanwezige Indianen, noch de zonen der marrons, de boschnegers, gedragen zich heden ten dage zoodanig, dat met grond te verwachten is, dat zij zich weder in den vorm van een I. V. zullen vertoonen, al zou men zich gevallen kunnen denken, waarin bij eene eventueele grondige ontginning en „opening" van het binnenland der kolonie, botsingen met de arrogante en sluwe boschnegers niet uitgelsoten zouden zijn.

Hetgeen zich echter ook heden ten dage als een mogelijke I. V. voor kan doen, is dezelfde ,inlandsche vijand", die in elke maatschappij (en niet het minst in Europa) op de loer ligt, om van een gunstig oogenblik gebruik te maken, tot den verrassenden aanval over te gaan.

Die I. V. wordt gevormd door elementen, welke altijd overal aanwezig zijn en wier doel is de maatschappelijke orde te verbreken tot tijdelijk voordeel van henzelven, maar tot groot en lang nawerkend nadeel voor het geheel.

Wat dit euvel aangaat, is Suriname zeker een bevoorrecht land. De bevolking heeft zeer zeker hare gebreken, maar zij is uiterst gemakkelijk te leiden, zoodat de politie in de kolonie zeker geen moeilijke taak heeft. Toch kent ook Suriname zijn „kwade elementen” onder de bewoners en de bevolking moge gemakkelijk te leiden zijn, het tropisch karakter van de inwoners maakt hen tot een gereede prooi voor ophitsing, terwij1 het ontvlambaar gemoed spoedig in lichter laaie staat.

Bovendien kunnen zich op de plantages, in de goudvelden en in de stad zelve arbeidersconflicten voordoen, die trouwens ook herhaaldelijk zijn voorgekomen en vaak een zeer ernstig karakter vertoonden. Men denke daarbij ook aan het groot aantal Britsch-Indiërs, dat tot dusver als arbeiders voor de plantages werd aangevoerd. Het getal op eind van I9I7 in de kolonie aanwezig bedroeg ongeveer 26.000 op eenen totale bevolking van nog geen I00.000.

Grensincidenten zijn - vooral aan den kant van FranschGuiana, geenszins uitgesloten en de plaag van de steeds uit deze Fransche strafkolonie ontvluchtende dwangarbeiders en 
de aan de grensrivier verblijvende maraudeurs vereischt voortdurende zorg van overheidswege.

Een en ander maakt het tot een dwingenden eisch, dat het bestuur te allen tijde beschikke over een kracht, die als „sterke arm" kan fungeeren, eene kracht, op welke volkomen kan worden vertrouwd en die daarom moet bestaan uit eene goed gedisciplineerde militaire macht van voldoende sterkte, uit Europeanen samengesteld.

Ook als reserve, waaruit in Suriname het Europeesche gedeelte van de politie wordt gevormd, kan in de kolonie de landmacht niet worden gemist en wellicht nog meer dan elders treedt daar de eisch òp den voorgrond, dat de troep van uitnemend gehalte zij.

Juist omdat Suriname een bij uitstek vreedzame kolonie is, waar niet - zooals in Oost-Indië - de prikkel bestaat van vaak voorkomende expeditiën in verschillende deelen van den Archipel, moet de landmacht in West-Indië uit goede elementen bestaan.

Officieren en manschappen mogen vooral niet te lang achtereen in dit tropisch garnizoen verblijven, slechts door eene veelvuldige verwisseling van uitgekozen officieren verkrijgt men den waarborg, dat een frissche geest levendig blijft onder het garnizoen. Slechts dáárdoor kan worden voorkomen, dat het tropisch klimaat zijn ongunstigen invloed doet gelden op het gehalte van den troep, zich uitende in verslapping van de krijgstucht, drankmisbruik, moreelen en physieken ondergang.

Den militairen leiders is een zware taak opgelegd, waar het hun plicht is, het aan hunne zorgen toevertrouwde troependeel tegen dien funesten invloed te beschermen en eene bestudeering van de wijze, waarop in de Britsche koloniën het militaire vraagstuk wordt opgelost zou zeker voor de landmacht in Suriname rijke vruchten kunnen opleveren.

De landmacht in Suriname heeft goede maar ook droevige dagen gekend - er zijn tijden geweest, dat de Nederlandsche militairen de driekleur die fier boven deze Hollandsch sprekende kolonie wappert, te schande waren, maar de oorzaak van die plichtverzaking moest steeds worden gezocht in Nederland.

De hoofdschuldigen bleken te zijn de bestuurders van het departement in den Haag, aan wien door het Nederlandsche volk de zorg voor de Nederzetting was toevertrouwd, 
doch die op laakbare wijze hunne taak veronachtzaamden.

Zeer zeker was gebrek aan belangstelling van de zijde van het Nederlansche volk mede daaraan schuld en daarom moet die belangstelling worden levendig gehouden. Men zij daarbij echter doordrongen van de waarheid, dat het niet voldoende is de aandacht te wijden aan de voordeelen, welke de kolonie zou kunnen opleveren; Suriname heeft door alle eeuwen heen geleden door den karaktertrek van de Hollanders, die uitgedrukt wordt in het bekende: ,giving too little and asking too much".

West-Indië heeft behoefte aan en recht op belangstelling, zich uitende in de noodige zorg van het moederland op elk gebied. Wordt aan die behoefte voldaan, dan zullen de voordeelen niet uitblijven en een der eerste eischen van staatszorg is de toerusting van het Bestuur der Kolonie met een corps degelijke ambtenaren en als macht, om zich onder alle omstandigheden te kunnen landhaven, eene goed uitgeruste, verpleegde en aangevoerde Europeesche troepenmacht.

Juni IgI9. 